Bartın University Journal of Faculty of Economics and Administrative Sciences, 2021, Volume 12, Issue 24

\title{
Koronavirüs (Covid-19) Pandemi Sürecinin Bartın İlindeki Kadın Girişimciler Üzerine Etkileri
}

\author{
Hülya MORKOÇ \\ Bartın Üniversitesi, Lisansüstü Eğitim Enstitüsü, İktisat ABD Yüksek Lisans Öğrencisi \\ morkochulya@gmail.com, OrcID: 0000-0002-2652-5871
}

Ebru KARABULUT

Bartın Üniversitesi, Lisansüstü Eğitim Enstitüsü, İktisat ABD Yüksek Lisans Öğrencisi ebruu.krabulut@gmail.com, OrcID:0000-0002 0084-8875

\section{Cansu AKTAŞOĞLU}

Bartın Üniversitesi, Lisansüstü Eğitim Enstitüsü, İktisat ABD Yüksek Lisans Öğrencisi cansuaktasoglu@gmail.com, OrcID: 0000-0002-5737-8739

\section{Doç. Dr. Ramazan ARSLAN}

Bartın Üniversitesi, İktisadi ve İdari Bilimler Fakültesi, İktisat Bölümü rarslan@ bartin.edu.tr, OrcID :0000-0002-4574-8819

\section{Öz}

İlk olarak Aralık 2019 tarihinde Çin'in Wuhan eyaletinde ortaya çıkan ve kısa zamanda hızla tüm dünyaya yayılan Covid-19 virüsü, küresel bir sorun olarak başta sağlık olmak üzere hayatın her alanını tehdit etmiş ve etmeye devam etmektedir. Bu çalışmada, Covid-19 sürecinde Bartın'da faaliyet gösteren kadın girişimcilerin maruz kaldıkları temel sorunlar irdelenmiş ve çözüm arayışları üzerinde durulmuştur. $\mathrm{Bu}$ nedenle Pandemi sürecinin getirdiği güçlükler de dikkate alınarak KOSGEB tarafından 2020-21 yıllarında destek alan toplam 35 kadın girişimci ile yüz yüze mülakat yapılmıştır. Yapılan görüşmelerde elde edilen verilerin analizi sonucunda Bartın'da faaliyet gösteren kadın girişimcilerin maruz kaldıkları sorunların başında ekonomik belirsizliklerin yer aldığı, bunu talep yetersizliği, evde artan sorumluluklar, aile üyelerinin temel gereksinimlerini karşılayamama, alınan desteklerin yetersiz olması ve yüksek kira fiyatlarıyla karşı karşıya kalma gibi sorunların takip ettiği görülmüştür.

Anahtar Kelimeler: Koronavirüs (COVID-19), Pandemi, Kadın Girişimciliği, Bartın

JEL Sınıflandırmaları: J01, J21, L26

APA: Morkoç, H., Karabulut, E., Aktaşoğlu, C. ve Arslan, R. (2021). Koronavirüs (Covid-19) Pandemi Sürecinin Bartın İlindeki Kadın Girişimciler Üzerine Etkileri. Bartın Üniversitesi İktisadi ve İdari Bilimler Fakültesi Dergisi, 12 (24), 451-466.

APA: Morkoç, H., Karabulut, E., Aktaşoğlu, C. ve Arslan, R. (2021). The Effects of The Coronavirus (Covid19) Pandemic Process on Women Entrepreneurs in Bartın Province. Bartın University Journal of Faculty of Economics and Administrative Sciences, 12 (24), 451-466. 


\title{
The Effects of The Coronavirus (Covid-19) Pandemic Process on Women Entrepreneurs in Bartın Province
}

\begin{abstract}
The Covid-19 virus, which first appeared in Wuhan, China in December 2019 and spread rapidly all over the world in a short time, continues to threaten all areas of life, especially health, as a global problem. In this study, the main problems faced by women entrepreneurs operating in Bartın during the Covid-19 process were examined and the search for solutions was emphasized. Therefore, taking into account the difficulties brought by the pandemic process, face-to-face interviews were conducted with a total of 35 women entrepreneurs who received support by KOSGEB in 2020-21. As a result of the analysis of the data obtained from the interviews, the main problems faced by women entrepreneurs operating in Bartın are economic uncertainties, such as insufficient demand, increased responsibilities at home, inability to meet the basic needs of family members, insufficient support received and high rental prices. problems appeared.
\end{abstract}

Keywords: Coronavirus (COVID-19), Pandemic, Women's Entrepreneurship, Bartın

JEL Classification: J01, J21, L26

\section{Giriş}

1980'lerden bu yana hızlı bir gelişim gösteren girişimcilik faaliyetleri, erkeklerle beraber kadınların da dâhil olduğu bir sürece girmiştir. Kadınların iş yaşamına büyük oranda dâhil olması ve aktif olarak girişimcilik etkinliklerinde bulunmaları gelişmekte olan ülkeler için "stratejik" olarak önemlidir. Son yıllarda tüm dünyada yaşanan dönüşümler kadınları da etkisi altına alarak onları çalışma hayatının vazgeçilemeyen aktörleri haline getirmiştir. İş hayatında iyi kazanmanın, atıl potansiyeli etkin konuma getirmenin ve yeni iş alanları oluşturmanın esas yolu kadın girişimciliğinin teşvik edilmesinden geçmektedir. Sanayi devrimi sürecine kadar kadınların sorumlulukları çok net bir biçimde evdeki yükümlülükler olarak belirlenmişken sonraki süreçte kadınların toplumdaki konumunda önemli dönüşümler meydana gelmiştir. Günümüzde iş gücüne dâhil olan kadın girişimciler artış göstermiş ve ailenin tüm maddi yükümlülügünü tek başına alan anneler daha fazla görülmeye başlamıştır (Soysal, 2010: 85).

2019 yılının sonlarına doğru ilk olarak Çin'in Wuhan kentinde ortaya çıkan COVİD-19 tüm dünyada yıkıcı etkileri olan küresel sorun haline gelmiş bir salgın olarak ifade edilmektedir. Bu salgın, Dünya Sağlık Örgütü aracılığıyla "Pandemi" şeklinde ilan edilmiştir. Çok kısa sürede hızlı bir biçimde yayılan bu salgın, bireylerin davranışlarını, hayat tarzlarını, alışkanlıklarını tamamen değiştirmelerine sebep olmuştur. Hala etkisinin tüm dünyada görüldüğü COVİD-19 salgını sürecinde oluşturulan mesafe kuralı, çeşitli kısıtlamalar ve yasaklar, işletmelerin geçici süreyle kapatılması yaşanılan dönüşümlerin başlıca örnekleridir. COVID-19 salgınının insan 
The Effects of The Coronavirus (Covid-19) Pandemic

hayatında yol açacağı dönüşümler günümüzde sorgulanan, merak edilen konular olarak yer almıştır (Akbaş ve Dursun, 2020: 79-80).

Çalışma, Covid-19 Pandemi sürecinin Bartın ilinde faaliyet gösteren kadın girişimciler üzerinde meydana getirdiği psiko-sosyal ve ekonomik etkileri araştırmayı amaçlamaktadır. Bu anlamda Bartın ilinde yapılan ilk alan çalışması olması bakımından önemli ve özgün değer taşıdığı düşünülmektedir. Araştırmanın hedef kitlesi başlangıçta Bartın ilindeki tüm kadın girişimciler olarak belirlenmiş olsa da Pandemi sürecinin getirdiği kısıtlar nedeniyle sadece KOSGEB’ten destek alan 35 kadın girişimci olarak yeniden belirlenmiştir. Araştırma yönteminde, yarı yapılandırılmış mülakat tekniği tercih edilmiş, bu tercih doğrultusunda söz konusu katılımcılarla yüz yüze görüşme yapılmıştır. $\mathrm{Bu}$ çalışmada COVID-19 'un Bartın ilinde faaliyet gösteren kadın girişimciler üzerindeki ekonomik etkileri, sosyal etkileri ve karşılaştıkları çeşitli sorunlar ortaya konulmuş ve çözüm önerileri sunulmuştur.

\section{Literatür Taraması}

Kadın girişimciliğiyle ilgili yapılmış pek çok çalışmaya rastlamak mümkündür. Surinder Pal Singh (2008), kadın girişimciliğine yönelik engellerin en başında kadınların iş hayatında sosyal açıdan kabul görmemesi, aile sorumlulukları, cinsiyet eşitsizliği, bankaların kadın girişimcilere verdikleri kredi yetersizlikleri gibi faktörler üzerinde durmuştur. Öneri olarak mikro işletmelerin teşviki, kurumsallaşmanın önemli olduğu ve kadın girişimcilere yönelik ayrı destek programlarının uygulanması gerektiğini vurgulamıştır.

Melike Gül ve Kudret Gül (2018), çalışmasında Balıkesir ilinde yiyecek sektöründe faaliyet gösteren kadın girişimcilerin niteliklerini, genel profilini, iş kurma aşamasında ve sonrasında yaşadıkları sorunları ele almıştır. Çalışmanın verileri Balıkesir ilinde 2012'den 2017'ye kadar Küçük ve Orta Ölçekli Sanayiyi Geliştirme ve Destekleme İdaresi Başkanlığı'ndan (KOSGEB) kredi desteği alan 60 kadın girişimcilerden elde edilmiştir. Verilerin elde edilmesi sürecinde mülakat ve anket tekniği uygulanmıştır. Veri analizinde frekans ve betimleyici istatistik analizleri kullanılmıştır. Bununla birlikte mülakat yolu ile elde edilen veriler de konularına göre sınıflandırılarak değerlendirilmiştir. Çalışma sonucunda kadın girişimcilerin özelliklerinin özgüvenli olmaları, başarılı olmaları ve ekonomik özgürlüklerini elde etmeleri ortaya konulmuştur.

Jennifer E. Jennings, Candida G. Brush (2013), çalışmalarında birçok kadın girişimciliği araştırmalarına benzer biçimde genel girişimcilik koşullarına uygun konulardan bahsedilmesine rağmen, kadın girişimciliğinin cinsiyetçi bir olgu olarak var olduğunu girişimcilik faaliyetlerinin en başında ailevi nedenlerin yer aldığını ve fırsatların ise gerekliliklerden dolayı meydana geldiği belirtilmiştir. Kadın girişimcilerin ekonomik bağımsızlığının aksine hedeflerine odaklı olarak ilerlediği vurgulanmıştır.

Sayın (2011) çalışmasında, Aydın ilindeki kadın girişimcilerin toplumsal ve iş yaşamındaki temel problemleri, erkek girişimcilerin kadın girişimciler ile kıyaslanmasını destekleyecek uygulamalar irdelenmiş ve çok yönlü analiz edilmiştir. 

İlindeki Kadın Girișimciler Üzerine Etkileri

Analiz sonucu kadın girişimcilerin yeterli mesleki eğitim almadıkları tespit edilmiştir. Yöntem olarak anket yöntemi ve betimleyici istatistikler kullanılmış ve geçerli 34 anket çalışması ile bulgular ortaya koymuştur. Araştırmaların sonucunda ise sözü edilen kadın girişimcilere mesleki şartın getirilmesi, ataerkil aile yapısı baskısının azaltılması ile kadın girişimcilerin etkinliğinin arttırılması da bir başka çözüm yolu olarak belirtilmiştir.

Kadın girişimciliğiyle ilgili yapılan araştırmalar, kadınların işgücüne katılmalarıyla özgür bir statü kazandıklarını ve de ekonomik canlılığa katk1 sağladıklarını göstermiştir (Soysal,2010: 85; Demir ve diğ, 2017: 320; Kocacık ve Gökkaya, 2005: 214-215).

Akbaş ve Dursun (2020), COVID (19) pandemi sürecinde kadın girişimciliği başlığı altında ele alınan çalışmalarında, çalışan kadınların özel alanlarını kamusal alana sığdırmak durumunda kaldıklarını bu süreçle birlikte online eğitim ve evden çalışmanın etkisiyle kadına ait rol tanımlarının yeniden şekillendiğini ortaya koymuştur. Kadınlar erkeklerden çok daha zor çalışma hayatına katılmış, birtakım meslek grupları kadınlarla özdeşleştirilmiştir. Bu da onları kariyerleri konusunda ilave engellere maruz bırakmıştır. Bununla birlikte koronavirüs (COVİD-19) süreci, çalışma ve aile yaşamı arasındaki istikrarsızlığı daha belirgin hale getirmiştir (Kavas ve Develi, 2020: 100). Bu çalışmaların yanı sıra kadın girişimciliğiyle ilgili uygulama örneklerinden ve çalışmaları yürüten pek çok kurumdan söz etmek de mümkündür ${ }^{1}$.

$\mathrm{Bu}$ çalışma, Bartın il özelinde kadın girişimcilerin pandemi döneminden etkilenme durumlarını ele alarak sürecin kadın girişimcilerde meydana getirdiği psikososyal ve ekonomik etkileri bakımından literatüre katkı sağlamayı amaçlamaktadır.

\section{Dünya'da ve Türkiye'de Kadın Girişimciliği}

\subsection{Dünyada Kadın Girişimciliği}

Dünya toplum tarihinde, kadınların işgücüne katılımı 18. Yüzyılın başlarında İngiltere'de gerçekleşen ve dünyanın büyük bir kısmına yayılan sanayi devrimi ile başlamıştır (Güleç, 2011: 38). Sanayi Devriminin başlamasıyla birlikte emeğini faaliyete dönüştüren kadın girişimciler, tarih boyunca üretimin büyük bir kısmında yer almışlardır. İlk kez kadınlar, işçi konumundan ücretli çalışan statüsüne geçerek işgücü piyasasına yönelmiş ve bu sayede emeğini değerlendirmişlerdir. Çalışma çevresini

\footnotetext{
${ }^{1}$ Kadın girişimciliğini teşvik etme ve iyileştirme kapsamında Türkiye İş Kurumu (IŞSKUR), Kadının Statüsü Genel Müdürlüğü (KSGM), Sosyal Riski Azaltma Projesi (SRAP), Kadın Emeğini Değerlendirme Vakfı (KEDV), Kadınlarla Dayanışma Vakfı (KADAV), Başbakanlık, Devlet Planlama Teşkilatı (DPT), Kadın Merkezi (KAMER), Türkiye Cumhuriyeti Küçük ve Orta Ölçekli İşletmeleri Geliştirme ve Destekleme İdaresi Başkanlığı (KOSGEB), Çok Amaçlı Toplum Merkezi (ÇATOM), Türkiye Kalkınma Vakfı (TKV), Ticari Bankalar (Vakıfbank, Ziraat Bankası, Halk Bankasi), Türkiye Grameen Mikro Kredi gibi uygulamalar ve kurumlar belirtilebilir (Toksöz, 2007: 75-76).
} 
genişleten kadınlar daha çok cinsiyete göre yeni iş alanları keşfetmişlerdir. Sanayi devrimi ile kadının işgücü çevresindeki payı artmaya başlamıştır (Tekin, 2019: 34).

1990'lı yıllarda İngiltere'de kadınlar, kendi işinin patronu olanların \%25'ni oluşturmaktaydılar. Yalnızca bu bahsedilen gelişimin İngiltere'ye mahsus olmamakla birlikte bütün Avrupa birliğine üye ülkelerde benzer bir seyirde ilerlediği söylenebilir (İyicil, 2006: 45). Bugün bakıldığında dünya ülkelerinin çoğunda, kadınların iş yaşamına adım atarken erkeklerin aksine daha dezavantajlı olduğu ve özel destekler ile teşviklerin artırılması gerekliliği kabul edilmektedir. İş yaşamında kadınların başarıları göz önüne alındığında kadınlara verilen desteğin önemi ortaya çıkmaktadır (Memiş, Paksoy ve Paksoy, 2007: 141).

Tablo 1 : Dünyada Kadın ekonomik Göstergeleri, (2010-2019)

\begin{tabular}{|c|c|c|c|c|c|}
\hline Yıllar & $\begin{array}{c}\text { Kadın } \\
\text { Nüfusu } \\
\text { (toplam } \\
\text { nüfusun } \\
\text { yüzdesi) }\end{array}$ & $\begin{array}{c}\text { İşsizlik, } \\
\text { (kadın } \\
\text { işgücünün } \\
\text { yüzdesi) }\end{array}$ & $\begin{array}{c}\text { İş gücü, } \\
\text { (toplam } \\
\text { işgücünün } \\
\text { yüzdesi) }\end{array}$ & $\begin{array}{c}\text { İşverenler, } \\
\text { (kadın } \\
\text { istihdamının } \\
\text { yüzdesi) }\end{array}$ & $\begin{array}{c}\text { İstihdamın } \\
\text { nüfusa } \\
\text { oranı, 15+, } \\
\text { kadın (\%) }\end{array}$ \\
\hline 2010 & 49,581 & 6,09 & 39,09 & 1,28 & 45,80 \\
\hline 2011 & 49,580 & 5,93 & 38,98 & 1,29 & 45,56 \\
\hline 2012 & 49,580 & 5,92 & 38,88 & 1,32 & 45,31 \\
\hline 2013 & 49,582 & 5,91 & 38,85 & 1,34 & 45,11 \\
\hline 2014 & 49,584 & 5,78 & 38,83 & 1,34 & 44,97 \\
\hline 2015 & 49,585 & 5,82 & 38,85 & 1,37 & 44,85 \\
\hline 2016 & 49,585 & 5,87 & 38,86 & 1,39 & 44,71 \\
\hline 2017 & 49,584 & 5,75 & 38,87 & 1,41 & 44,69 \\
\hline 2018 & 49,584 & 5,53 & 38,85 & 1,44 & 44,69 \\
\hline 2019 & 49,583 & 5,52 & 38,88 & 1,45 & 44,68 \\
\hline
\end{tabular}

Kaynak: World Bank, 2021

Dünyada kadının ekonomik göstergelerine bakıldığında kadın nüfusu 2010'dan 2019'a artış göstermiştir. Bu oran 2010 yılında 49,581 iken 2019 yılında 49,583 olmuştur. Kadın işsizlik oranı 2010 yılında 6,09 iken 2019 yılında 5,52 olarak gerçekleşmiştir. Aynı zamanda işveren kadınların oranı 2010 yılına kıyasla 2019'da 

İlindeki Kadın Girișimciler Üzerine Etkileri

giderek bir artış kaydetmiştir. Bu oranlar, kadın istihdamının dünyada giderek arttığını göstermektedir.

\subsection{Türkiye'de Kadın Girişimciliği}

Kadınlar yıllar içinde, dönemin şartlarına göre farklı şekil ve statülerde çeşitli ekonomik etkinliklere dâhil olmuştur. Bununla beraber kadınlar, temel olarak ilk defa sanayi devrimi ile ücretli veyahut işçi statüsünde iş hayatında bulunmuşlardır. Tarihi süreçte farklı statülerde ekonomik etkinliklerin içerisinde sosyal bir varlık olarak etkin bir biçimde konumlanmışlardır. $\mathrm{Bu}$ doğrultuda iş hayatındaki rolleri de giderek değişiklik göstermiş ve gelişme kaydetmiştir (Biner, 2011: 45).

Türkiye'de 1980'li dönemler, kadın girişimciliğinin ve kadınların iş hayatında bulunmalarının hızlandığı bir dönem olarak görülmektedir. Kadın hareketliliğiyle ilgili başlıca üç safhadan söz edilebilir. Osmanlı Dönemi, Cumhuriyet'in ilanının müteakiben ilk dönem ve 1980'den sonrası dönem (Gökakın, 2000: 109-123).

Türkiye'de kadınların girişimcilik adına etkinlikleri temelinde yapısal uyum politikalarının tesiri ile azalan hane halkı gelirlerine özgü oluşturulan "kadınların tek başlarına küçük işletme açma girişimlerine” dayanmaktadır. Kadınların hem kendi hanelerine ekstra gelir sağlaması hem de ücretli olarak çeşitli işlerde çalışma oranlarının artmasıyla birlikte onların ekonomik etkinliklerde bulunması da hız kazanmıştır. Fakat Türkiye'de kadınların iş tecrübesinin yeterli olmaması ve iş hayatına adım atmalarının önemli ölçüde az olması sebebiyle kadınları kendi işini kurmaya ya da çalışmaya mecburi olarak yöneltmektedir (Soysal, 2010: 94-95). Kadın girişimciliği, ekonomik ve sosyal yaşama önemli firsat ve avantajlar sunmaktadır. Girişimciliğin ekonomik olarak ilerlemeye ve iş ortamına farklı yöntemler sağladığı da bir gerçektir. Ülke ekonomisinin ilerleyişinde kadınlar farklı potansiyel girişimcilik etkinlikleri doğrultusunda önemli bir kaldıraç kuvveti meydana getirmektedir (Minniti ve Arenius, 2003: 3).

\section{Grafik 1: Çalışma Yaşam Süresi, (2013-2018) (Yıl)}

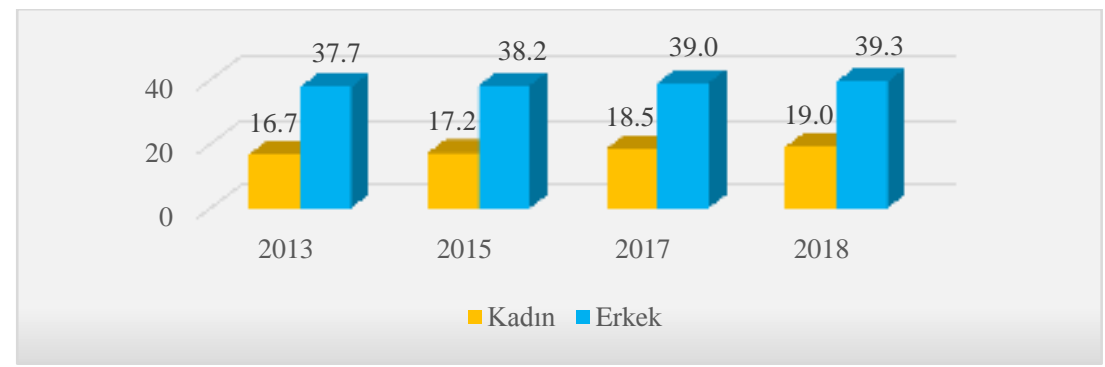

Kaynak: TÜİK, Hane Halkı İşü̈cü Araştırması, 2013-2018

İş yaşamında bulunma ve kalma süresi, bir bireyin tüm hayatı süresince işgücü piyasasında daha etkin olması beklenilen yıl sayısı şeklinde ifade edilmektedir. Buna göre Grafik 1'de hane halkı iş gücü göstergelerinden 2013-2018 yılları aralığında 
çalışma yaşamı süresi gösterilmiştir. Grafikte 2013 yılında kadınlardaki çalışma süresi 16.7 yıl iken erkeklerde 37.7 yıl olarak görülmektedir. 2015 yılında kadın ve erkeklerdeki bu çalışma süresi sırasıyla 17.2 'den 38.2 yıla çıkmıştır. Nihayetinde 2018 yılında çalışma süresi kadınlarda 19.0 yıl erkeklerde ise 39.3 olarak gerçekleşmiştir (Grafik: 1). Bu da kadın ve erkeklerde çalışma sürelerinin yıl itibariyle bir artış kaydettiğini göstermektedir.

Tablo 2: Mevsim Etkisinden Arındırılmamış İş Gücü Verileri (15+Yaş/Bin Kişi) (2019-2020)

\begin{tabular}{|l|c|c|c|c|c|c|}
\hline & \multicolumn{2}{|c|}{ Kadın } & \multicolumn{2}{c|}{ Erkek } & \multicolumn{2}{c|}{ Toplam } \\
\hline Yıllar & $\mathbf{2 0 1 9}$ & $\mathbf{2 0 2 0}$ & $\mathbf{2 0 1 9}$ & $\mathbf{2 0 2 0}$ & $\mathbf{2 0 1 9}$ & $\mathbf{2 0 2 0}$ \\
\hline Nüfus & 30990 & 31509 & 30270 & 30811 & 61261 & 62320 \\
\hline İstihdam & 9055 & 7982 & 19144 & 17631 & 28199 & 25614 \\
\hline İşücü & 10681 & 9197 & 21720 & 20191 & 32401 & 29308 \\
\hline $\begin{array}{l}\text { İşücüne Dâhil } \\
\text { Olmayan Nüfus }\end{array}$ & 20310 & 22312 & 8550 & 10620 & 28860 & 32932 \\
\hline İşsiz Sayısı & 1626 & 1215 & 2576 & 2559 & 4202 & 3775 \\
\hline İstihdam Oranı (\%) & 29,2 & 25,3 & 63,2 & 57,2 & 46,0 & 41,1 \\
\hline $\begin{array}{l}\text { İşücüne Katılım } \\
\text { Oranı (\%) }\end{array}$ & 34,5 & 29,2 & 71,8 & 65,5 & 52,9 & 47,2 \\
\hline İşsizlik Oranı (\%) & 15,2 & 13,2 & 11,9 & 12,7 & 13,0 & 12,8 \\
\hline
\end{tabular}

Kaynak: : TÜİK, İş Gücü İstatistikleri Nisan 2020

Tablo 2'de istihdam oranı 2019 yılında kadınlarda \%29.2 iken 2020 y1lında bu oran \%25.3'e düşmekte ve aynı şekilde istihdam oranı erkeklerde 2019 yılında \%63.2 iken 2020'de \%57.2 şeklinde azalış göstermiştir. İş gücüne katılım oranlarına bakıldığında 2019 yılında kadınlarda \%34.5 iken 2020 yılında \%29.2 olarak bir azalış göstermiştir. İş gücüne katılım oranı 2019'dan 2020'ye hem kadınlarda hem de erkeklerde azalmıştır. Bu azalış, 2019 yılı sonlarında ortaya çıkan ve hala etkisi devam eden pandemi sürecine bağlı olarak açıklanabilir.

Tablo 3: Seçilmiş ülkelerde kadın işgücü ve toplam kadın girişimci oranları (\%) (2012)

\begin{tabular}{|l|c|c|}
\hline $\begin{array}{l}\text { Ülke/Ülke } \\
\text { Grupları }\end{array}$ & $\begin{array}{c}\text { Kadınların İş Gücüne } \\
\text { Katılım Oranı }\end{array}$ & $\begin{array}{c}\text { Kadın Girişimcilerin } \\
\text { Toplam Girişimcilere Oranı }\end{array}$ \\
\hline \hline Avrupa Birliği & 59 & 28 \\
\hline \hline ABD & 72 & 41 \\
\hline \hline Türkiye & 27 & 6.5 \\
\hline \hline OECD & 62 & 25 \\
\hline
\end{tabular}

Kaynak: (Kaygın ve Güven, 2013: 57) 

İlindeki Kadın Girișimciler Üzerine Etkileri

Tablo 3'e göre ekonomide yer alan işletmelerin $\mathrm{AB}$ ülke gruplarında yüzde 28'ini, ABD'nin yüzde 41'ini ve OECD ülke gruplarının ise yüzde 25'ini kadın girişimciler oluşturmaktadır. Söz konusu oranlar Türkiye'de 2012 yılında yüzde 6.5 olarak gerçekleşmiştir. Dolayısıyla Türkiye'de hem kadınlarda iş gücüne katılım oranı hem de kadın girişimcilerin toplam girişimcilere Oranı tabloda belirtilen ülke gruplarının gerisinde seyretmiştir.

Tablo 4: Cinsiyete göre Girişimcilik Oranları, (\%) (2018)

\begin{tabular}{|c|c|c|}
\hline Girişimcilik & $\begin{array}{c}\text { 18-64 Yaş Aralığında Yer } \\
\text { Alan Kadın Nüfusu } \\
\text { İçerisinde Kadın } \\
\text { Girişimci Oranı }\end{array}$ & $\begin{array}{c}\text { 18-64 Yaş Aralığında Yer } \\
\text { Alan Erkek Nüfusu } \\
\text { İçerisinde Erkek } \\
\text { Girişimci Oranı }\end{array}$ \\
\hline $\begin{array}{c}\text { Kurumsal Hale Gelmiş } \\
\text { Girişimciler }\end{array}$ & 1.50 & 4.70 \\
\hline $\begin{array}{c}\text { Erken Dönemde Yer } \\
\text { Alan Girişimciler }\end{array}$ & 8.10 & 19.96 \\
\hline $\begin{array}{c}\text { Yeni İş Sahibi Olan } \\
\text { Girişimciler }\end{array}$ & 3.50 & 10.70 \\
\hline $\begin{array}{c}\text { Kurulma Aşamasında } \\
\text { Yer Alan Girişimciler }\end{array}$ & 4.60 & 44.9 \\
\hline $\begin{array}{c}\text { İşletme Kurmak İsteyen } \\
\text { Girişimciler }\end{array}$ & 26.00 & 10 \\
\hline
\end{tabular}

Kaynak: (Durukan, 2021: 23)

Tablo 4'te, kurulma aşamasında yer alan girişimciler ile yeni iş sahibi olan girişimcilerin toplamı, erken dönemde yer alan girişimler olarak ifade edilmiştir. Buna göre Türkiye'de erken dönem kadın girişimcilerin oranı 8.39 iken erkek girişimcilerin oranı 19.96 olarak belirlenmiştir. Kurumsal olan kadın girişimci oranlarına bakıldığında kadın girişimcilerin oranı yüzde 1.50 iken erkek girişimcilerin oranı ise yüzde 4.70'dur. Aynı şekilde 18-64 yaş aralığında işletme kurmak isteyen kadın girişimci oranı 26.0 iken erkek girişimci oranı ise 44.9 olarak gerçekleşmiştir. Bu oranlar, Türkiye'de gelinen noktada kadın girişimcilerin erkek girişimcilere göre oranlarının hala düşük olduğunu göstermektedir.

Türkiye'de COVID-19 sürecinden etkilenen kadın girişimciler ve işletmeler adına sunulan çözüm önerileri arasında KOSGEB'in yeni yapılan destek programı da bulunmaktadır. KOSGEB'in bu program ile pandemi sürecinde mikro ve küçük ölçekli işletmeler için 3 yıl geri ödemesi olmadan ve faizsiz bir şekilde 5 Milyar TL bütçeli bir program başlattığı bilinmektedir. Destek programında küçük ölçekli işletmeler 75 bin TL ve mikro ölçekli işletmeler ise 30 bin TL'ye kadar maddi yardım alabilmektedirler.

Diğer bir destek faaliyeti ise Türkiye Cumhuriyeti Aile ve Sosyal Hizmetler Bakanlığı aracılığıyla verilmekte olup bu faaliyet, düzenli bir biçimde sosyal yardımlardan faydalanan hanelerin Ekonomik İstikrar Kalkanı Paketi destek faaliyeti kapsamında 1000 TL nakdi yardım verilmesi uygun görülmüştür (KOSGEB, 2021; T.C Aile ve Sosyal Hizmetler Bakanlığg,2020). Kadın girişimciliğinin arttırılması ve çözüm 
önerileri adına yapılan kuruluşlar ve destek programlarından bir diğeri de TİM-TEB Girişim Evidir. Girişim Evi, 2018'de kurulmuş ve toplamda 54 üyesi vardır. Kurum, geçmişten günümüze dek yaklaşık 150 kadın girişimciye destek sağlamıştır. Bununla birlikte destek sağlanan kadın girişimcilerin yüzde 60'lık kısmı İstanbul dışında bulunmakta ve binden fazla kişiye istihdam olanağı tanınmaktadır. Bu destek ile birlikte kadın girişimcilerin toplam cirosu 158 milyon TL şeklinde gerçekleşmektedir (DHA, 2021).

\section{Koronavirüs (Covid-19) Pandemi Sürecinin Bartın İlindeki Kadın Girişimciler Üzerine Etkileri}

\subsection{Araştırmanın Amacı ve Yöntemi}

Çalışmanın amacı, Covid-19 Pandemi sürecinin Bartın ilindeki kadın girişimcilerin üzerine olan etkilerini tespit etmek, bu tespitlerden hareketle çözüm önerileri sunmaktır. Bu çalışma, Bartın il özelinde pandemi sürecinin kadın girişimciler üzerindeki etkilerini inceleyen ilk çalışmalardan biri olma özelliğini taşıdığından özgün bir çalışma olarak değerlendirilmektedir. KOSGEB Bartın Müdürlüğü’nden alınan bilgiye göre, 2017-2021 yıllarında desteklenen girişimci sayısı 275'tir. Aynı yıllarda desteklenen kadın girişimci sayısı ise 125 olup bunların 2020-2021 pandemi dönemindeki sayısı 35'tir. Araştırmanın amacı doğrultusunda pandemi sürecinin getirdiği sınırlılıklar dikkate alınarak daha detaylı ve anlamlı verilere rahat ulaşım kolaylığı sağlayan 35 kadın girişimciye yarı yapılandırılmış mülakat tekniği uygulanmıştır. Katılımcılarla yapılan yüz yüze görüşmelerden önce yarı yapılandırılmış bir mülakat formu hazırlanmış ve soruların çoğu açık uçlu sorulardan oluşturulmuştur. Mülakat süresince ses kayıt cihazı kullanılmamış ve katılımcıların görüşleri yazılı olarak kaydedilmiştir. Açık uçlu sorular bağlamında elde edilen cevaplar incelenerek betimsel analiz yapılmış ve sonuçlar buna göre yorumlanmıştır. Betimsel analiz, bilindiği gibi farklı veri toplama yöntemleriyle sağlanan verilerin uygun şekilde özetlenmesi ve yorumlanmasına dayanan bir nitel veri analiz türüdür (Toprakcı Alp ve Namal, 2019:187).

\subsection{Araştırmanın Önemi ve Kapsamı}

Covid-19, küresel boyutta bir tehdit unsuru olarak ortaya çıkmış ve tüm dünyada sosyo-ekonomik hayat üzerinde önemli etkiler meydana getirmiştir. $\mathrm{Bu}$ tehditten etkilenen önemli bir kesim de hiç şüphesiz kadın girişimciler olmuştur. Bu çalışmada Bartın ilindeki kadın girişimcilerin pandemi sürecinde etkilenme durumları araştırılmakta ve araştırma sonunda ortaya çıan sorunlarına çözüm üretebilme amaçlanmıştır. Bu anlamda Bartın ilinde yapılan ilk çalışma olduğu için önemli ve özgün olma niteliği taşımaktadır. Dolayısıyla çalışmanın kapsamını Bartın ilinde faaliyet gösteren ve KOSGEB desteğinden yararlanan kadın girişimciler oluşturmaktadir. 

İlindeki Kadın Girișimciler Üzerine Etkileri

\subsection{Araştırmanın Bulguları}

Tüm dünyada derin etkileri görülen, küresel boyutta etkileri halen süren COVIDD19 salgını, başta sosyal hayatımız olmak üzere kültürel ve ekonomik hayatı da derinden etkilemiştir. $\mathrm{Bu}$ etkilerin her biri ayrı bir çalışmanın konusu olarak görülebilir. $\mathrm{Bu}$ çalışmada, pandemi sürecinin Bartın ilindeki kadın girişimciler üzerinde meydana getirdiği etkiler araştırılmıştır. Salgın öncesi dönemde, sermaye yetersizliği, ekonomik belirsizlikler, personel temininde güçlükler, aile içi sorumluluklar, psikolojik ve sosyal bakımdan yeterince destek alınmaması gibi ekonomik ve toplumsal yaşamla ilgili sorunlar yaşayan katılımcılar, salgın dönemiyle birlikte bu sorunların etkisini daha derinden hissetmişlerdir (Gül ve Gül, 2018: 85; Arslan ve Toksoy, 2017: 134-135). Çalışma kapsamında kadın girişimcilerin karşılaştıkları sorunlar ekonomik, sosyal ve psikolojik bulgular olmak üzere üç temel başlık altında incelenmiştir.

\subsubsection{Katılımcılara Ait Demografik Bulgular}

Katılımcıların demografik özelliklerine göre yaş Aralıklarının 18-60 Aralığında olduğu görülmüştür. Bu aralık, genç girişimci sayısının giderek arttığını ve yaşla birlikte tecrübenin de önem kazandığını göstermektedir. Eğitim düzeyleri lise ve üniversite olarak belirlenmiştir. Katılımcıların genelde evli oldukları, bekâr olanların sayı olarak az olduğu saptanmıştır. Kadın girişimciler gıda,-perakende, turizm ve tekstil gibi iş kollarında faaliyet göstermektedirler.

\subsubsection{Katılımcılara Ait Ekonomik Bulgular}

Bartın ilinde mülkiyeti kendisine ait olan kadın girişimcilerin kiracı konumunda olan kadın girişimcilere kıyasla pandemi sürecinden daha az etkilendikleri görülmüştür. Öyle ki kiracı kadın girişimciler, yüksek kiralarla karşı karşıya kaldıkları için işletmelerini kapatma durumuna gelmişlerdir.

Bir kadın girişimıi olmanın birçok avantaj ve dezavantajları vardır. Avantaj kabul edilen faktörlerden en önemlisi girişimci olmanın kadına özgüven ve ekonomik bağımsızlık kazandırdığıdır. Kendileriyle görüşülen kadın girişimciler pandemi sürecinde kadın girişimci olmanın avantajlarını aile ile daha sık vakit geçirme, evdeki sorumluluklar ve bu süreçte dinlenme firsatı elde etmek şeklinde dile getirirken dezavantajlarını ise ekonomik belirsizliklerin başlaması, talep yetersizliği, kira fiyatlarının ödenemez hale gelmesi ile yüksek vergi oranları olarak ifade etmişlerdir. Görüşülen kadın girişimcilerin büyük çoğunluğu talep yetersizliğinden şikâyet ederken belirli bir kısmı ise ekonominin gidişatı hakkında tedirgin olduğunu ifade etmiştir.

Kadın girişimciler, daha az sermayeye gerek olan sektörlere yöneldiklerini ve onlar için en önemli sorunun sermaye yetersizliği olduğunu ifade etmişlerdir. Pandemi sürecinde ise sermaye bulmaktaki zorluk giderek daha büyük bir sorun haline gelmiştir. Sermaye desteği konusunda devletin yanlarında olmasını isteyen katılımcılar görüşlerini şu sözlerle dile getirmişlerdir. 
The Effects of The Coronavirus (Covid-19) Pandemic

“...Devletimizin ticaret yapanın yanında olmasını. Her türlü desteğini versin istiyoruz...” (Katılımcı 3). “...Bir kadın girişimci olarak çevre baskılarının kadınlar üzerindeki etkisi azaltılmalı, kadına yönelik çalışmalar çoğaltılmall, devlet yeni iş kuracak kadınlara her türlü desteği vermeli..." (Katılımcı 4).

Dünya genelinde olduğu gibi Türkiye'de de kadın girişimciliği alanında yapılan devlet destekleri geçmişten günümüze giderek önem kazanmaktadır. Nitekim KOSGEB'den pandemi süreci ve sonrasına dair (2017-2021) Bartın ilinde toplam 125 kadın girişimciye 10.096.913,33 TL destek sağlanmıştır. Pandemi dönemi ile birlikte (2020-2021) ise 35 kadın girişimciye yapılan destek miktarı 2.816.479,73 TL'dir ${ }^{2}$. İşletme sahibi olan kadın girişimcilerin pandemi döneminde karşılaştıkları en temel sorunları arasında alım gücünün giderek azalması, vergi oranlarının çok yüksek olması, bulunulan süreçten ötürü ekonomik belirsizlikler çerçevesinde çalışanların maaşlarının ödenememesi ve dolayısıyla zorunlu ücretsiz izin sistemine geçilmesi gibi bulgulara rastlanılmıştır. Belirtilen bulgular çerçevesinde kadın girişimciler, sağlanan destek ve fonların yetersiz olduğunu ve yalnızca minimum harcama ve ihtiyaçlarının karşılandığını ifade etmişlerdir. Bu konunun çözümü için katılımcılar görüşlerini şu sözlerle dile getirmişlerdir:

“...Kadınlarımız cesur olup mesleği olmasa bile mutlak yapacă̆ bir iş vardır. Yerimizi açarken devletimiz zorluk çıkarmasın istiyorum vergiler yüksek olmasın, çocuk bakımında destek olunmal,, devlet dairelerinde evrakların düzenlenmesi konusunda yardımcı olunmalı..." (Katılımcı 5).

“...Pandemi dolaylslyla bazı ödemeler konusunda esneklik getirilebilir, stopaj olamayabilir, özellikle pandemi dolayısıyla satış yapamadı̆̆ımız için kira desteği yapabilir. Elektriğimizde indirim yapabilir, KOSGEB ten iş yerimi kurarken destek aldım gayet memnunun. Bartın da KOSGEB dışında alternatif kuruluşlar olmalı ki Bartın da kadın girişimci sayısı artsın. Bir iş yeri açmak için mutlaka devletten destek alıyorsun onun için devlet desteği biz kadınların her zaman yanında olsun..." (Katılımcı 11).

Katılımcılara pandemi sürecinin onları nasıl etkilediği sorulduğunda ise büyük bir kısmı var olan birikimlerini kullandığı ifade ederken kalan diğer kısmı bu sürecin onları borçlanmaya iterek negatif etkisi olduğunu dile getirmiştir ${ }^{3}$.

\footnotetext{
${ }^{2}$ T.C. Küçük ve Orta Ölçekli İşletmeleri Geliştirme ve Destekleme İdaresi Başkanlığı KOSGEB Bartın Müdürlüğü, 06.09.2021 tarih ve E-25805398-622.03 -555 sayılı yazı.

${ }^{3}$ Kendileriyle görüşme yapılan kadın girişimciler, ciroları konusunda bilgi vermekte isteksiz davranmışlardır. Bu nedenle katılımcıların pandemi öncesi ve sonrası ciroları karşılaştırılamamış dolayısıyla kazanç ve kayıpları da hesaplanamamışıtır.
} 

İlindeki Kadın Girișimciler Üzerine Etkileri

Katılımcıların devletten beklentileri arasında vergi oranlarının en aza indirilmesi, teşviklerin iyileştirilmesi, alternatif destek fonlarının oluşturulması ve yüksek kira fiyatlarının düşürülmesi öne çıkmıştır. Katılımcıların tamamına yakını hem kira fiyatlarından hem de yüksek vergi oranlarından yakınırken bir yandan da destek fonlarının arttırılması gerektiği konusunda hemfikir oldukları görülmüştür.

\subsubsection{Sosyal Bulgular}

Bartın'daki kadın girişimcilerin iş yeri açmadan önce mesleki bir eğitim aldığına dair bulgulara bakıldığında katılımcıların bir kısmının iş yeri kurmadan önce çeşitli kurumlar tarafından açılan eğitim kurslarına katılarak hem kendilerini geliştirmeyi amaçladığı hem de gerekli iş yeri açma belgelerini tamamlamak istediği belirtilmiştir. Kadınlar mesleki eğitim aldıkları merkezlerde öğrendikleri bilgi ve becerileri girişimcilik faaliyetlerinde uyguladıklarını dile getirmişlerdir.

Pandemi sürecinde kadın girişimci olmanın sosyal alanlardaki avantaj ve dezavantajlarına bakıldığında; COVID-19 önlemleri doğrultusunda oluşan kısıtlamalar sonucu kadın girişimciler hem aile içi sorumlulukları ile ilgilenme hem de aile üyeleriyle daha sık vakit geçirme olanağı bulmuşlardır. Bu sebepten ötürü pandemi süreci onlara bir bakıma avantaj sağlamıştır. Bununla beraber seyahat kısıtlamaları, sosyal ve kültürel aktivitelerin olmaması kadın girişimeciler için dezavantaj haline gelmiştir.

Dünya genelinde olduğu gibi Türkiye'de de pandemi döneminde kadın girişimcilerin normal rutinde yaptıkları tüm faaliyetler bu süreçte daha da zorlayıcı hale gelmiştir. Eğitime ara verilmesi, hijyen kuralları ve diğer kısıtlamalar sebebiyle normalde yardım aldıkları tüm işleri kendileri üstlenmek zorunda kalmışlardır. Görüşme yapılan katılımcıların büyük bir kısmı aile içi sorunlarla baş ederek herhangi bir destek almadıklarını dile getirirken, azınlık bir grup ise herhangi bir sorun yaşamadığını ve dolayısıyla bir desteğe ihtiyacı olmadığını belirtmiştir. Bu sorunların asgari düzeyde olmasını sağlamak için eğitimin şart olduğunu belirten katılımcılar bu konudaki görüşlerini şu sözlerle dile getirmişlerdir:

\section{“...Teşvik ve destek olarak maddeler çoğaltılmalıdır. Tabi bunun} yanında kadın girişimciler için devlet desteği kesinlikle olmazlarsa olmazlarımız, iş kurmadan önce mutlaka ĕ̆itim verilmeli çünkü yasal evraklar nasıl düzenlenir, kar zarar nasıl yapılmalı, satış yapılırken nelere dikkat edilmeli, daha birçok husus üzerinde eğitim verilmeli gerçi ben iş kur üzerinde girişimcilik sertifikası aldım. Ĕgitim kadın girişimciler için şart...” (Katılımcı 9). “...Toplumumuzda öncellikle kız çocuklarının eğitilmesini ve bu çocukların yetiştirdiği düzgün insanların sayısının fazla olmasını temenni ediyorum. Her ne kadar 21. Yy da olsak da ataerkil düşünce siteminden çıkmamış bir toplumuz. Eğitim ile bu durumu aşabiliriz diye düşünüyorum..." 
The Effects of The Coronavirus (Covid-19) Pandemic

İşletme sahibi kadın girişimcilerin COVİD-19 süreciyle birlikte aile içi sorumlulukların artması ve bu süreçte konulan yasaklar sebebiyle çalışma yaşamlarının sekteye uğraması gibi bulgulara ulaşılmıştır. Ayrıca katılımcılar sürecin onlar üzerinde olumsuz bir etki bıraktığını dile getirmiştir.

\subsubsection{Psikolojik Bulgular}

İnsanların yaşadıkları kötü dönemlerde zorlu şartlar altında çeşitli stres tepkileri vermesi ve kayg1 sürecinin oluşması beklenen bir durumdur. COVID-19 süreci değerlendirildiğinde yaşanılan kaygı durumu kişinin tamamen kendisi ile ilgili değildir. Kişi kendisi kadar tüm aile bireyleri ve sevdikleri adına da endişe duymaktadır. Koronavirüs hastalığına yakalanma riski, salgının ne zaman sonlanacağının bilinmemesi, önlemlerin yeterli olduğundan emin olunmaması gibi durumlar toplumsal yaşamda psikolojik olarak baskı hissetmeye, endişe ve stres bozukluklarının artış göstermesine sebep olmaktadır. Yapılan çalışmalarda pandeminin bilhassa tansiyon, şeker veya KOAH gibi kronik rahatsızlıkları olanların ve 65 yaş üzeri kişilerin riskli grup olarak saptandığını işaret etmekle beraber yaşanan süreç oluşan endişe ve kaygı durumunu dünya genelinde yaygın hale getirmiştir. En temel sorun bu dönemde yaşanan kayg1 ve stres bozukluğudur. Görüşme yapılan katılımcılar da belirtilen bu benzeri sorunlarla karşı karşıya kaldıklarını belirtmişlerdir.

\section{Sonuç ve Öneriler}

Günümüzde kadın girişimciliği önemli boyutta hız kazanmıştır. Türkiye özelinde de son yıllarda girişimci kadınların çalışma hayatına dâhil olmalarıyla beraber ekonomik, kültürel ve sosyal hayatları daha aktif duruma gelmiştir. Kadının iş hayatına dâhil olması, ekonomik özgürlüğe sahip olması anlamına geldiğinden toplumdaki konumunu ve statüsünü de değiştirmektedir. Kadınların girişim faaliyetlerinde bulunmalarının temel nedenleri; bütün toplumsal alanlarda daha bağımsız olmak, bireysel karar süreçlerine diğer bireylerin saygı göstermesini sağlamak ve daha kararlı bir biçimde kendilerini kanıtlamak olarak sıralanabilir. Bu bağlamda, girişimcilik faaliyetlerinde bulunan kadınlar, ekonomik ve sosyal yaşamda çeşitli olanaklar yaratarak içinde bulundukları ülke ekonomisini iyileştirmede ve istihdam ile iş firsatı yaratmada önemli katkılar ortaya koymaktadır.

Yakın dönemde en fazla sorgulanan konular içerisinde kuşkusuz COVID-19'un ekonomik ve toplumsal alanlar başta olmak üzere hayatımızda yol açacağı değişiklikler yer almaktadır. Bu salgının bulaşıcılık riski yüzünden, başladığı an itibariyle tüm dünyada endişe ve kaygı ortamı oluşturarak ülkeleri büyük çaplı tedbirler almak zorunda bırakmıştır. Özellikle Türkiye'de 10 Mart 2020'den itibaren ilk vakanın görülmesiyle vaka sayılarının süratli artış göstermesi tüm kısıtlama ve yasakları da beraberinde getirmiş ve gündelik hayattaki rutinlerin değişiklik göstermesine neden olmuştur.

Bu çalışma ile COVID-19'un Bartın ilinde faaliyet gösteren kadın girişimciler üzerindeki etkilerine dikkat çekilmesi amaçlanmıştır. Çalışmada sosyo-ekonomik ve 

İlindeki Kadın Girișimciler Üzerine Etkileri

psikolojik olmak üzere önemli sonuçlara ulaşılmıştır. Öncelikle Bartın ilindeki kadın girişimcilerin bilhassa mikro ölçekli işletmelerde faaliyet gösterdikleri tespit edilmiştir. Pandeminin başladığı ve devam ettiği son iki yılda (2020-21) KOSGEB'den 35 kadın girişimcinin destekten yararlandığı, bu girişimcilere toplam 2.816.479,73 TL tutarında destek sağlandığı tespit edilmiştir.

Pandemi sürecinde kadın girişimcilerin genel olarak ekonomik belirsizlikler, talep yetersizliği, aile içi sorumlulukların artması, kira fiyatlarının karşılanamaması, vergi oranlarının yüksek olması, teşvik ve desteklerin yetersiz olması, alternatif fon kaynaklarının bulunmaması gibi önemli sorunların etkisi altında kaldıkları saptanmıştır. Ayrıca COVID-19'un getirdiği kısıtlamalarla hem aile içi sorumluluklarının arttığı hem de aile üyeleriyle daha sık vakit geçirme olanağı buldukları bu anlamda pandemi sürecinin onlara bir bakıma avantaj da sağladığı görülmüştür. Bununla birlikte bir takım seyahat kısıtlamaları, sosyal ve kültürel aktivitelere katılamama gibi bir takım olumsuz hususlar kadın girişimciler için bir dezavantaj olarak ifade edilebilir.

Kadın girişimcilerin pandemi sürecindeki sorunlarının en aza indirilmesi, ülke ekonomisine katılımlarının sağlanması ile girişimcilik potansiyelinin hayata geçirilmesi adına bir takım tedbirler alınabilir. Bu bağlamda Bartın ölçeğinde tespit edilen bulgular doğrultusunda kadın girişimciliğine verilen destekler arttırılmalı, kadınlara ait istihdam politikaları geliştirilmelidir. Pandemi sürecinde destek sağlayan kurum ve kuruluşlar aracılığıyla kadın girişimcilere imtiyaz sağlanmalıdır. Girişimci kadınlara yönelik uzun vadeli teşvik verilmeli ve vergi muafiyetlerinin arttırılması yoluna gidilmelidir. Son olarak örgün ve yaygın eğitim kurumlarının desteğiyle, kadın girişimcilere yönelik eğitim düzeyleri artırılmalı, böylece toplumda daha güçlü bir konuma gelmeleri sağlanmalıdır.

\section{Kaynakça}

Aile, Çalışma ve Sosyal Hizmetler Bakanlığı, (2020). https://www.aile.gov.tr/duyurular/2-milyon-111-bin-haneye-1-000-er-tl-nakdidestegin-odeme-tarihleri-aciklandi/ (Erişim Tarihi: 13.11.2021)

Akbaş, Ö. Z. ve Dursun, C. (2020). Korona virüs (COVID-19) Pandemisi Sürecinde Özel Alanına Kamusal Alanı Sığdıran Çalışan Anneler. Avrasya Sosyal Ve Ekonomi Araştırmaları Dergisi,7(5).

Arslan, İ. K. ve Toksoy, M. D. (2017). Türkiye'de Kadınları Girişimciliğe Yönelten Faktörler Karşılaştıkları Sorunlar ve Çözüm Önerileri. İstanbul Ticaret Üniversitesi Girişimcilik Dergisi, 1(1), 123-148.

Biner, H. (2011). Ekonomide Kadın Girişimciliğin Yeri: Türkiye'de Az Gelişmiş Bölgeler Üzerine Bir İnceleme. Yayınlanmamış Yüksek Lisans Tezi, Şanlıurfa Harran Üniversitesi Sosyal Bilimler Enstitüsü, Şanlıurfa. 
Demir, E., Çoban M. S. ve Yılmaz A. B. (2017). Türkiye'de Kadın Girişimciliği: Kadın Girişimciliğinin Özellikleri, Sorunları ve Türkiye'deki Durumu Hakkında Bir Değerlendirme Women Entrepreneurship In Turkey: A Profession. Sosyal Bilimler Enstitüsü Dergisi, (38), 303-324.

Demirören Haber Ajansı, Pandemide Kadın Girişimci Oranı Arttı,(15.04.2021). Erişim Adresi https://www.dha.com.tr/ekonomi/pandemide-kadin-girisimci-orani-artti/ (Erişim Tarihi 12.11.2021)

Durukan, L. (2021). Türkiye'de Kadın Girişimcilerin Desteklenmesinde KOSGEB' in Rolü. Gazi İktisat İşletme Dergisi, 7(1), 17-37.

Gökakın, Z. Ö. (2000). Doksanlı Yılların Yeni Kahramanları: Türkiye'de Girişimci Kadın Profili, 8.Yönetim ve Organizasyon Kongresi Bildiriler Kitabı, Nevşehir, 109-123.

Güleç, S. (2011). Kadın Girişimciliği-Karaman Örneği. Yayınlanmamış Yüksek Lisans Tezi, Karamanoğlu Mehmetbey Üniversitesi Sosyal Bilimler Enstitüsü, Karaman.

Gül, M. ve Gül, K. (2018). Balıkesir İlinde Kadın Girişimci Profili ve Sorunları: Yiyecek Sektöründe Bir Uygulama. Dumlupınar Üniversitesi Sosyal Bilimler Dergisi, (56),82-96.

Toprakcı Alp, G. ve Namal, N.A. (2019). Toplumsal Cinsiyet Bağlamında Türkiye'deki Sendikacılığın Mevcut Durumu: Antalya İli Örneği. Emek Araştırma Dergisi (GEAD), 10(15), 171-200.

İyicil, A. G. (2006). Avrupa Birliği'ne Giriş Sürecinde Türkiye'deki Kadın Girişimciliğinin İrdelenmesi ve bir Araştırma.. Yayınlanmamış Yüksek Lisans Tezi, Gazi Üniversitesi Sosyal Bilimler Enstitüsü, Ankara.

Jennings, J, E. ve Brush, G. (2013). Research on Women Entrepreneurs: Challenges to (and from) the Broader Entrepreneurship Literature?. The Academy of Management Annals, 7(1), 663-715.

Kavas, B. N. ve Develi, A. (2020). Çalışma Yaşamındaki Sorunları Bağlamında Covid19 Pandemisinin Kadın Sağlık Çalışanları Üzerindeki Etkisi. Uluslararası Anadolu Sosyal Bilimler Dergisi, (2), 84-112.

Kaygın, E. ve Güven, B. (2013). Kadın Girişimcilik: Farklı Boyutlarıyla. Veritas Akademi.

Kocacık, F. ve Gökkaya, V.B. (2005). Türkiye'de Çalışan Kadınlar ve Sorunları. Cumhuriyet Üniversitesi İktisadi ve İdari Bilimler Dergisi, 6(1), 195-2017. 
Minniti, M. ve Arenius P. (2003). Women in Entrepreneurship. In The Entrepreneurial Advantage of Nations: First Annual Global Entrepreneurship Symposium. (Vol. 29). United Nations.

Memiş, H., Paksoy, H. M. ve Paksoy, S. (2007). Bölgesel Kalkınmada Kadın Girişimciliğinin Önemi: Gap Bölgesinde Bir Araştırma.

Sayın, E. (2011). Kadın Girişimcilerin Sorunlarının Betimleyici Analizi. Organizasyon Ve Yönetim Bilimleri Dergisi, 3(1), 23-32.

Singh, S. P. (2008). An Insight into the Emergence of Women-Owned Businesses as an Economic Force in India. In special Conference of the Strategic Management Society (pp. 12-14).

Soysal, A. (2010). Türkiye'de Kadın Girişimciler: Engeller ve Firsatlar Bağlamında Bir Değerlendirme. Ankara Üniversitesi SBF Dergisi, 83-114.

T.C. Küçük ve Orta Ölçekli İşletmeleri Geliştirme ve Destekleme İdaresi Başkanlığ KOSGEB Bartın Müdürlüğü, 06.09.2021 Tarih ve E-25805398-622.03 -555 Sayılı Yazı.

T.C. Küçük ve Orta Ölçekli İşletmeleri Geliştirme ve Destekleme İdaresi Başkanlığı, https://www.kosgeb.gov.tr/site/tr/genel/detay/7800/pandemiden-etkilenenisletmelere-5-milyar-tl ( Erişim tarihi: 13:11.2021) .

Tekin, Z. (2019). Yerel Kalkınmada Kadın Girişimciliğinin Önemi : Iğdır Örneği.Yayınlanmamış Yüksek Lisans Tezi, Iğdır Üniversitesi Sosyal Bilimler Enstitüsü İktisatAnabilim Dalı İktisat Bilim Dalı, Iğdır.

The World Bank (2021). https://www.worldbank.org/tr/country/turkey adresinde alındı.

Toksöz, G. (2007). İş Gücü Piyasasının Toplumsal Cinsiyet Perspektifinden Analizi ve Bölgeler Arası Dengesizlikler. Çalışma ve Toplum, 4(15), 57-79.

TÜİK. (2020). İş Gücü İstatistikleri, Nisan 2020, Eylül 6, 2020 tarihinde Türkiye İstatistik Kurumu Web Sitesi: http://www.tuik.gov.tr/PreHaberBultenleri.do?id=33788 adresinden alınd.

TÜİK . (2018). Ulusal Eğitim İstatiskleri Veri Tabanı, 2018, Eylül 4, 2020 tarihinde Türkiye İstatistik Kurumu Web Sitesi: http://tuik.gov.tr/PreTablo.do?alt_id=1018 adresinden alındı. 